\title{
Characteristics of Wastewater Taken from A Pool Water System: Analysis of Physicochemical and Phytotoxicological Parameters in Terms of Recyclability
}

\author{
Edyta Łaskawiec $1, *$ \\ 1 Silesian University of Technology, Faculty of Environmental and Power Engineering, Department of Water \\ and Wastewater Engineering, Stanislawa Konarskiego Street 18, 44-100 Gliwice, Poland \\ * Correspondence: edyta.laskawiec@gmail.com (E.Ł)
}

\begin{abstract}
The presented research focused on the possibility of reusing washings from rising filters for the maintenance of greenery. For this purpose, a physicochemical assessment of the washings was carried out, the washings were subjected to a preliminary treatment - dechlorination and sedimentation. Then, washings solutions (5-100\%) were prepared in water matrices: deionized water, tap water, and rainwater, and selected physicochemical parameters were checked again. The ecotoxicological assessment was performed with the use of selected plant indicators: Lemna minor, Sinapis alba, Lepidium sativum. The stimulating effect of the addition of washings on the germination of S. alba and L. sativum was observed. This phenomenon depended on the water matrix in which the washings were dissolved and on the concentration of the washings. Moreover, L. minor was an organism with a higher sensitivity to the ingredients contained in the washings. It should be noted that the physicochemical quality of the washings was subject to changes during the study, which had a major impact on the results of the phytotoxicological assessment.
\end{abstract}

Keywords: swimming pool; washings; ecotoxicology; circular economy; closed circuit; recycling

\section{Introduction}

Each public swimming pool must have its own pool water treatment circuit. Circuits of this type operate as closed systems in which the water is continuously treated and disinfected. Water splash losses are continuously replenished with tap water that normally feeds the circuit [1]. The process commonly used for the treatment of swimming pool water is filtration through porous beds (sand, sand with hydroanthracite, zeolite, with filter glass, etc.). Regardless of the bed structure and filter material, each bed must be periodically cleaned - rinsed. In the case of pressure filters supported by contact coagulation, the beds are rinsed with a stream of air and water (from the equalizing tank) in the opposite direction to that of normal filtration (backwashing). As a result, a stream of wastewater - washings, rich in impurities washed out of the bed, suspensions, and flocs after the coagulation process, is obtained [2,3]. The washings are usually discharged directly to the sewage system. Systems for the recovery of heat from washings are used increasingly often, less often they are recycled or used in toilet bowls. It should be noted that to carry out a proper rinsing process, the DIN standard recommends the use of $4-6 \mathrm{~m}^{3}$ for each $\mathrm{m}^{2}$ of filter bed. In the case of larger facilities, this generates large volumes of washings, which have the potential for re-use [4,5].

The aim of the research was to analyze the possibility of using the washings to maintain greenery during periods of rainfall deficiency, thus limiting the consumption of tap water. As part of the analysis, the physicochemical quality of the collected washings was assessed, enriched with the phytotoxicity assessment.

\section{Materials and Methods of research}




\subsection{Subject of study}

The subject of the research were washings samples taken from the swimming pool circuit. The circulating water is purified by a multi-layer filter bed (quartz sand - hydroanthracite). The filter bed was rinsed every 24 hours, each time the facility was closed. There are three identical beds in circulation, the single rinsing of which generates over $30 \mathrm{~m}^{3}$ of washings. Washings samples were taken from the settling tank during the rinsing of the beds into plastic containers with a capacity of 10 liters. The next day, in the morning, physicochemical analyses of the washings were carried out. The washings were subjected to the sedimentation process for 24 hours to reduce the content of total suspended solids. Then, solutions containing washes with a concentration of 5, 10, 25, 50, 75, 100\% were prepared in water matrices: deionized water, tap water, rainwater. Washings samples were collected for 10 weeks, physicochemical and ecotoxicological assessments were performed for each of the prepared solutions.

\subsection{Physicochemical analyzes}

The assessment of the quality of the washings and their solutions included the analysis of physicochemical parameters. Selected parameters are presented in this work. The $\mathrm{pH}$ was determined by the potentiometric method (Multiparameter meter inoLab ${ }^{\circledR} 740$ /WTW, Measuring and Analytical Technical Equipment, (Wroclaw, Poland)). The total suspended solids (TSS) content was determined by the method of filtration through glass fiber filters [6]. The free and total chlorine and potassium concentrations were determined colorimetrically using cuvette tests. Total nitrogen, cyanuric acid, phenol index, aluminum, chlorides, zinc were determined spectrophotometrically (UV-VIS Spectroquant ${ }^{\circledR}$ Pharo 300, Merck, Dramstadt, Germany). The concentration of total organic carbon (TOC) was determined by catalytic combustion (TOC-L series, Shimadzu, Kyoto, Japan). The presented values are the arithmetic mean with standard deviation (Mean \pm SD) of 10 independent samples (Table 2).

\subsection{Phytotoxicity assessment}

Phytotests with Lemna minor were conducted based on OECD recommendations [7]. $8 \mathrm{~cm}^{3}$ of tested samples were dispensed into threaded vials made of transparent glass with a capacity of 12 $\mathrm{cm}^{3}$. L. minor was placed in the vials, the number of fronds was noted on the day the test was started (day 0). The effect of the analyzed samples on the test organisms was determined based on changes in the 7-day tests. Three repetitions of the test were performed for each of the tested solutions. The tests determined the average specific growth rate from moment time i to $\mathrm{j}$ from equation $\mu_{i-j}[-](1)$ and percent inhibition in average specific growth rate $\mathrm{I}_{\mathrm{r}}[\%]$ according to formula (2) [7]:

$$
\mu_{i-j}=\frac{\ln \left(N_{j}\right)-\ln \left(N_{i}\right)}{t_{j}-t_{i}}
$$

where: $\mathrm{N}_{\mathrm{j}}$ - number of fronds observed in the test or control vessel at time $\mathrm{j} ; \mathrm{N}_{\mathrm{i}}$ - number of fronds observed in the test or control in vessel at time $i$; $t_{i}-$ moment time for the start of the period, $t_{j}-$ moment time for the end of the period.

$$
I_{r}=\frac{\mu_{C}-\mu_{T}}{\mu_{c}} \cdot 100, \%
$$

where: $\mu c-$ mean value for $\mu$ in the control; $\mu$ т - mean value for $\mu$ in treatment group (washings solutions).

Control samples consisted of deionized water, tap water, and rainwater, respectively, depending on the tested washings solution matrix. Negative frond growth inhibition values mean stimulation of their growth. The samples are classified according to the magnitude of the toxic effect: $\mathrm{I}_{\mathrm{r}}<25 \%$ - nontoxic; $I r=25.1-50 \%$ - low toxic; $I r=50.1-75 \%$ toxic; $\operatorname{Ir}=75.1-100 \%$ - highly toxic [8].

The phytotoxicity of the washings and their solutions, using Lepidium sativum and Sinapis alba, was assessed based on the Phytotoxkit ${ }^{\circledR}$ procedure [9]. $5 \mathrm{ml}$ of test samples were poured on Petri dishes (in triplicate for each test), and then 10 pieces of L. sativum and S. alba seeds were sown on each 
of the samples, the plates were placed in a laboratory incubator (Elkon) at a temperature of $25^{\circ} \mathrm{C}$. The number of sprouted seeds and the length of the roots were read after 24, 48, 72, and 96 hours. Value of the coefficient relative germination percentage RGP [\%] was determined based on formula (3). While relative radicle growth RRG [\%] was determined from equation (4):

$$
R G P=\frac{G_{S}}{G_{C}} \cdot 100, \%
$$

where: Gs - the number of germinated seeds in the test sample; Gc - number of germinated seeds in the control sample.

$$
R R G=\frac{L_{S}}{L_{C}} \cdot 100, \%
$$

where: Lc - root length of germinating seeds in the control sample [mm]; Ls - root length of germinating seeds in the test sample [mm].

In this study, the presentation of the results was based on the value of the germination index GI [-], determined from equation (5), and the obtained values were classified based on the values presented in Table 1 [10].

$$
G I=\frac{R G P \cdot R R G}{100}
$$

Table 1. Toxicity classification based on the germination index GI [10].

\begin{tabular}{cc}
\hline Germination Index Value & Effect \\
\hline GI $\geq 100$ & Growth stimulation \\
$100>$ GI $\geq 80$ & Non-toxicity \\
$80>$ GI $\geq 50$ & Moderate toxicity \\
$50>$ GI & High toxicity \\
\hline
\end{tabular}

All assays were carried out in triplicate, and the results were expressed as mean \pm SD. Means and standard deviation were calculated using the MS Excel statistical package. Student's t-test was used to determine the significance between the analyzed and the control sample. A difference was considered significant if the $p$-value was less than 0.05 ( $p<0.05)$.

\section{Results}

\subsection{Physicochemical assessment}

The raw washings (after sampling) were characterized by a high content of total suspended solids of $142.50 \pm 59.10 \mathrm{mg} / \mathrm{L}$ (Table 2). Attention should be paid to the significant standard deviation from the arithmetic mean, i.e. the differentiated amount of suspension during the test period. Moreover, an increased concentration of chlorine was noted, which made it impossible to discharge the washings directly into the soil. The value of the remaining physicochemical parameters was low to the extent that meant that the washings could be reused [11]. The 24-hour sedimentation process in the Imhoff funnel allowed for a significant reduction in the total suspended solids content $(32.50 \pm$ $6.80 \mathrm{mg} / \mathrm{L})$. Moreover, a reduction in the concentration of free chlorine $(0.05 \pm 0.05 \mathrm{mgCl} / \mathrm{L})$ was obtained (as a result of free dechlorination), which allowed for an ecotoxicological assessment of washings, while limiting the effect of chlorine as the main toxic factor for plants. Diluting the washings with selected water matrices also allowed reducing the concentration of pollutants in the solutions. It is particularly important to control the concentration of aluminum (the source in the washings are coagulants), which may be a toxic factor for plants (concentration in the raw washings $0.79 \pm 0.07 \mathrm{mgAl} / \mathrm{L})$.

Table 2. Physicochemical quality of washings and their solutions with a matrix: rainwater. 


\begin{tabular}{|c|c|c|c|c|c|c|c|c|}
\hline \multirow{2}{*}{ Parameter } & \multicolumn{8}{|c|}{ Share of washings in rainwater (Mean \pm SD) } \\
\hline & $\begin{array}{c}\text { Raw } \\
\text { washings }\end{array}$ & $0 \%$ & $5 \%$ & $10 \%$ & $25 \%$ & $50 \%$ & $75 \%$ & $100 \%$ \\
\hline $\mathrm{pH},-$ & $6.97 \pm 0.16$ & $\begin{array}{c}7.03 \pm \\
0.23\end{array}$ & $\begin{array}{c}7.03 \pm \\
0.23\end{array}$ & $\begin{array}{c}7.05 \pm \\
0.14\end{array}$ & $\begin{array}{c}6.95 \pm \\
0.22\end{array}$ & $\begin{array}{c}7.06 \pm \\
0.13\end{array}$ & $\begin{array}{c}6.99 \pm \\
0.15\end{array}$ & $\begin{array}{c}6.94 \pm \\
0.14\end{array}$ \\
\hline TSS, mg/L & $\begin{array}{c}142.50 \pm \\
59.19\end{array}$ & $\begin{array}{c}14.50 \pm \\
3.27\end{array}$ & $\begin{array}{c}15.33 \pm \\
3.14\end{array}$ & $\begin{array}{c}15.33 \pm \\
2.66\end{array}$ & $\begin{array}{l}16.00 \pm \\
3.03\end{array}$ & $\begin{array}{c}18.00 \pm \\
2.28\end{array}$ & $\begin{array}{c}20.33 \pm \\
3.27\end{array}$ & $\begin{array}{c}32.50 \pm \\
6.80\end{array}$ \\
\hline $\begin{array}{l}\text { Free chlorine, } \\
\quad \mathrm{mgCl}_{2} / \mathrm{L}\end{array}$ & $0.72 \pm 0.15$ & $\begin{array}{c}0.00^{*} \pm \\
0.00\end{array}$ & $\begin{array}{c}0.00 \pm \\
0.00\end{array}$ & $\begin{array}{c}0.00 \pm \\
0.00\end{array}$ & $\begin{array}{c}0.00 \pm \\
0.00\end{array}$ & $\begin{array}{c}0.00 \pm \\
0.00\end{array}$ & $\begin{array}{c}0.00 \pm \\
0.00\end{array}$ & $\begin{array}{c}0.05 \pm \\
0.05\end{array}$ \\
\hline $\begin{array}{l}\text { Total chlorine, } \\
\mathrm{mgCl}_{2} / \mathrm{L}\end{array}$ & $1.70 \pm 0.23$ & $\begin{array}{c}0.00 \pm \\
0.00\end{array}$ & $\begin{array}{c}0.00 \pm \\
0.00\end{array}$ & $\begin{array}{c}0.00 \pm \\
0.00\end{array}$ & $\begin{array}{c}0.00 \pm \\
0.00\end{array}$ & $\begin{array}{c}0.03 \pm \\
0.05\end{array}$ & $\begin{array}{c}0.05 \pm \\
0.09\end{array}$ & $\begin{array}{c}0.11 \pm \\
0.04\end{array}$ \\
\hline $\begin{array}{c}\text { Total nitrogen, } \\
\text { mgN/L }\end{array}$ & $7.65 \pm 0.61$ & $\begin{array}{c}8.42 \pm \\
0.97\end{array}$ & $\begin{array}{c}8.58 \pm \\
0.80\end{array}$ & $\begin{array}{c}8.80 \pm \\
1.12\end{array}$ & $\begin{array}{c}7.79 \pm \\
0.83\end{array}$ & $\begin{array}{c}7.58 \pm \\
0.44\end{array}$ & $\begin{array}{c}7.63 \pm \\
0.45\end{array}$ & $\begin{array}{c}7.60 \pm \\
0.66\end{array}$ \\
\hline $\begin{array}{l}\text { Cyanuric acid, } \\
\mathrm{mgC}_{3} \mathrm{H}_{3} \mathrm{~N}_{3} \mathrm{O}_{3} / \mathrm{L}\end{array}$ & $3.50 \pm 0.40$ & $\begin{array}{c}0.00 \pm \\
0.00\end{array}$ & $\begin{array}{c}0.00 \pm \\
0.00\end{array}$ & $\begin{array}{c}0.00 \pm \\
0.00\end{array}$ & $\begin{array}{c}0.00 \pm \\
0.00\end{array}$ & $\begin{array}{c}1.54 \pm \\
0.40\end{array}$ & $\begin{array}{c}1.59 \pm \\
0.39\end{array}$ & $\begin{array}{c}3.30 \pm \\
0.52\end{array}$ \\
\hline $\begin{array}{l}\text { Phenol index, } \\
\mathrm{mgC}_{6} \mathrm{H}_{6} \mathrm{O} / \mathrm{L}\end{array}$ & $0.42 \pm 0.05$ & $\begin{array}{c}0.00 \pm \\
0.00\end{array}$ & $\begin{array}{c}0.00 \pm \\
0.00\end{array}$ & $\begin{array}{c}0.00 \pm \\
0.00\end{array}$ & $\begin{array}{c}0.00 \pm \\
0.00\end{array}$ & $\begin{array}{c}0.17 \pm \\
0.04\end{array}$ & $\begin{array}{c}0.24 \pm \\
0.07\end{array}$ & $\begin{array}{c}0.35 \pm \\
0.05\end{array}$ \\
\hline $\begin{array}{l}\text { Aluminum, } \\
\mathrm{mgAl} / \mathrm{L}\end{array}$ & $0.79 \pm 0.07$ & $\begin{array}{c}0.00 \pm \\
0.00\end{array}$ & $\begin{array}{c}0.00 \pm \\
0.00\end{array}$ & $\begin{array}{c}0.00 \pm \\
0.00\end{array}$ & $\begin{array}{c}0.00 \pm \\
0.00\end{array}$ & $\begin{array}{c}0.13 \pm \\
0.05\end{array}$ & $\begin{array}{c}0.18 \pm \\
0.04\end{array}$ & $\begin{array}{c}0.78 \pm \\
0.05\end{array}$ \\
\hline Chlorides, mg/L & $\begin{array}{c}187.67 \pm \\
18.58\end{array}$ & $\begin{array}{c}83.00 \pm \\
17.32\end{array}$ & $\begin{array}{c}132.50 \pm \\
17.17\end{array}$ & $\begin{array}{l}134.33 \\
\pm 17.31\end{array}$ & $\begin{array}{c}142.83 \pm \\
19.69\end{array}$ & $\begin{array}{c}153.00 \pm \\
16.70\end{array}$ & $\begin{array}{c}151.67 \pm \\
20.17\end{array}$ & $\begin{array}{c}182.33 \pm \\
18.14\end{array}$ \\
\hline Zinc, mg/L & 0.00 & $\begin{array}{c}0.76 \pm \\
0.35\end{array}$ & $\begin{array}{c}0.67 \pm \\
0.33\end{array}$ & $\begin{array}{c}0.63 \pm \\
0.31\end{array}$ & $\begin{array}{c}0.61 \pm \\
0.19\end{array}$ & $\begin{array}{c}0.40 \pm \\
0.15\end{array}$ & $\begin{array}{c}0.10 \pm \\
0.12\end{array}$ & $\begin{array}{c}0.00 \pm \\
0.00\end{array}$ \\
\hline $\mathrm{TOC}, \mathrm{mgC} / \mathrm{L}$ & $9.91 \pm 1.00$ & $\begin{array}{c}0.42 \pm \\
0.66\end{array}$ & $\begin{array}{c}0.56 \pm \\
0.64\end{array}$ & $\begin{array}{c}0.61 \pm \\
0.64 \\
\end{array}$ & $\begin{array}{c}0.84 \pm \\
0.82 \\
\end{array}$ & $\begin{array}{c}2.12 \pm \\
0.58 \\
\end{array}$ & $\begin{array}{c}3.43 \pm \\
1.06 \\
\end{array}$ & $\begin{array}{c}9.40 \pm \\
0.98 \\
\end{array}$ \\
\hline
\end{tabular}

\subsection{Phytotoxicological assessment}

Depending on the concentration and the indicator organism used, either stimulation or inhibition of plant growth was observed. It should be noted that two independent 4-point scales were used for the classification of phytotoxicity (Table 3). For Lemna minor, there was low toxicity of the $100 \%$ washing solution in all analyzed matrices as well as for $75 \%$ washing solution in deionized water (inhibition of frond growth was $39.77 \pm 3.71 \%$ and $31.18 \pm 4.49 \%$ ). L. minor frond growth stimulation was noted in samples with $10 \%$ washing solution (matrix: deionized water); $5,25-75 \%$ washing solution (matrix: tap water), and partially from samples of washing solution with a concentration of 10, 25,75\% (matrix: rainwater). Sinapis alba and Lepidium sativum turned out to be less sensitive to the ingredients contained in the tested washings. None of the tested samples was toxic to plant growth. Moreover, for tests with L. sativum in washing solution with a concentration range from 5 to $75 \%$ (all matrices), stimulation of plant growth was observed (Table 3).

\section{Discussion}

The reuse of wastewater is an important aspect of water supply in areas with water shortages. However, the negative impact that may be associated with the migration of heavy metals, increased soil salinity, or phytotoxic effects should be considered [12]. The washings, although treated as wastewater, are of a much better quality, so can be reused. However, attention should be paid to the remains of coagulants and post-coagulation sludge in the washings. Since aluminum coagulants are commonly used in water treatment in swimming pool facilities, the presence of aluminum in the washings may contribute to growth inhibition (especially of roots), damage to the plant structure, or disturbance of nutrient uptake by plants, especially with longer irrigation with washings [13-15]. In short-term tests, it was shown that raw washes (100\% solution) can have phytotoxicological potential, which was observed in the 7-day Lemna minor biotest. No toxic effect was observed in short germination and growth inhibition tests (96 hours), which may be related to both the shorter duration of observation and the lower sensitivity of L. staivum and S. alba to washing components, including aluminum compounds [15]. 
Table 3. Phytotoxicity of washings solutions and classification of toxicity.

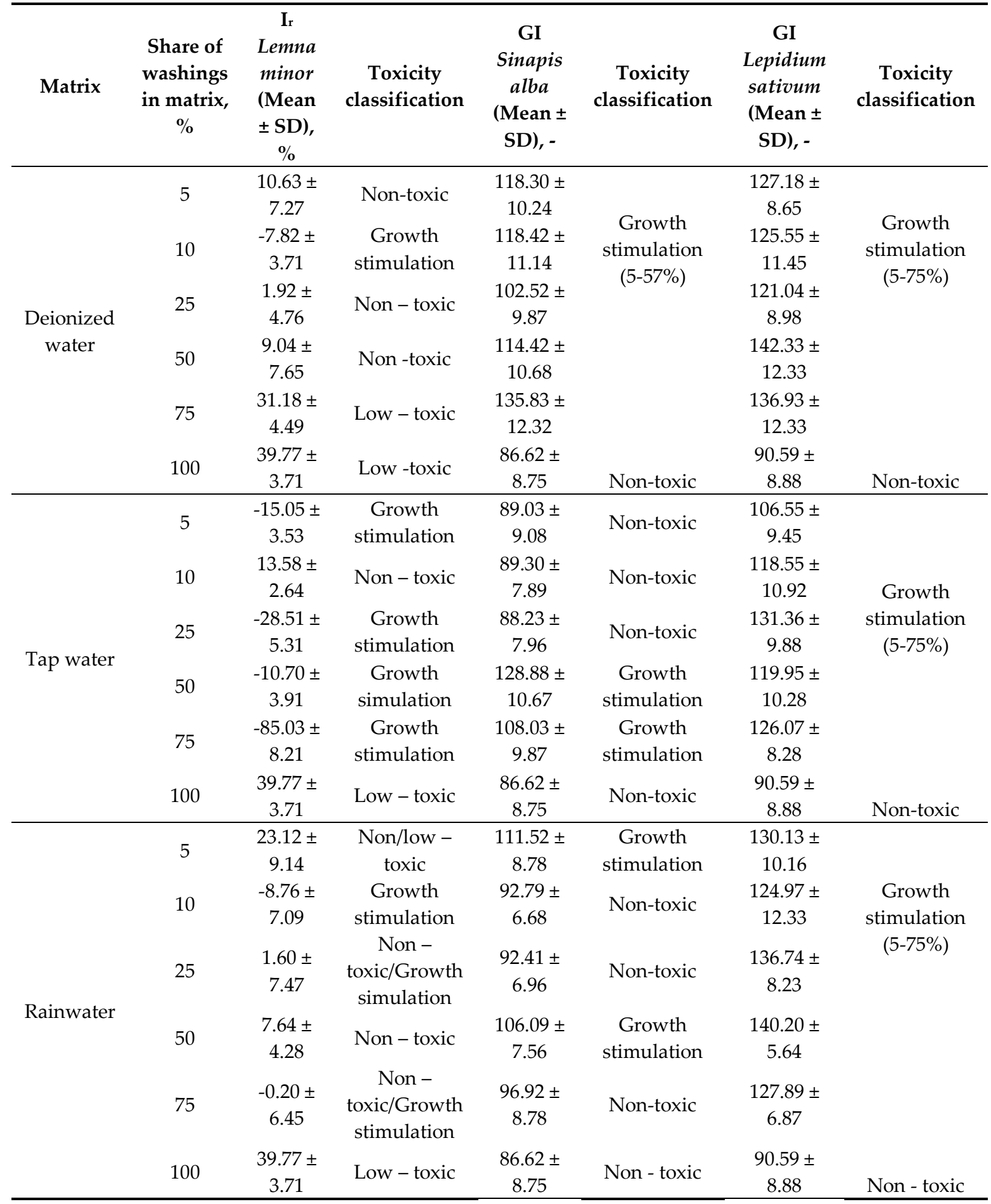

\section{Conclusions}

The use of washings from swimming pool facilities for the maintenance of greenery is an opportunity to reduce the consumption of tap water. Due to the presence of total suspended solids and chlorine remaining after the disinfection process, it is necessary to apply simple measures to improve their quality - sedimentation and de-chlorination. However, the presence of aluminum with prolonged use of washings can negatively affect both plants and soil. Therefore, the use of washings as the only source of plant nutrition may entail the risk of toxic effects.

Author Contributions: Conceptualization, methodology, formal analysis, writing-original draft preparation, writing - review and editing by E.Ł. 
Funding: This research received no external funding.

Acknowledgments: The work was carried out as part of the statutory research of the Faculty of Environmental and Power Engineering. The research was carried out using the infrastructure of the Department of Water and Wastewater Engineering.

Conflicts of Interest: The author declare no conflict of interest.

\section{References}

1. Wyczarska-Kokot J. The study of possibilities for reuse of washings from swimming pool circulation systems. Ecol Chem Eng S 2016, 23(3), pp. 447-459.

2. McCormick N., Porter M., Walsh M.E. Disinfection by-products in filter backwash water: implications to water quality in recycle designs. Water Res 2010, 44, pp. 4581-4589.

3. Wyczarska-Kokot J., Piechurski F. Application of pre-ozonation process in swimming pool water treatment technology. Desalin Water Treat 2020, 186, pp. 382-393.

4. Łaskawiec E., Dudziak M., Wyczarska-Kokot J. Assessment of the possibility of recycling backwashing water from the swimming pool water treatment system. Ecol Chem Eng A 2016, 23(4), pp. 401-410.

5. Skibinski B., Götze Ch., Worch E., Uhl W. Pore diffusion limits removal of monochloramine in treatment of swimming pool water using granular activated carbon. Water Res 2018, 132, pp. 270-281.

6. Water quality - Determination of suspended solids - Method by filtration through glass fibre filters (PNEN 872:2007/Ap1:2007).

7. Test No. 221: Lemna sp. Growth Inhibition Test, 2006, https://doi.org/10.1787/9789264016194-en.

8. Heish Ch.Y., Meng-Hsiun T., Ryan K., Pancorbo O. Toxicity of the 13 priority pollutant metals to Vibrio fisheri in thee Microtox ${ }^{\circledR}$ chronic toxicity test. Sci Total Environ 2004, 320, pp. 37-50.

9. Phytotoxkit: Seed germination and early growth microbiotest with higher plants. Standard Operational Procedure. MicroBioTest Inc., Nazareth, 2004, 24.

10. Venegas M., Leiva A.M, Vidal G. Influence of Anaerobic Digestion with Pretreatment on the Phytotoxicity of Sewage Sludge. Water Air Soil Pollut 2018, 229:381, pp. 1-11.

11. Council Directive of 21 May 1991 concerning urban waste water treatment (91/271/EEC), 1991L0271 - EN - 01.01.2014 - $004.003-1$.

12. Liang W., Sui L., Zhao Y., Li F., Liu L., Xie D. Ecotoxicity assessment of soil irrigated with domestic wastewater using different extractions. Front Environ Sci Eng 2015, 9(4), pp. 685-693.

13. Ovečka M., Takáč T. Managing heavy metal toxicity stress in plants: Biological and biotechnological tools. Biotechnol Adv 2014, 32, pp. 73-86.

14. Manas P. De las Heras J. Phytotoxicity test applied to sewage sludge using Lactuca sativa L. and Lepidium sativum L. seeds. Int J Environ Sci Technol 2018, 15, pp. 273-280.

15. Parra-Almuna L., Diaz-Cortez A., Ferrol N., de la Luz Mora M. Aluminium toxicity and phosphate deficiency activates antioxidant systems and up-regulates expression of phosphate transporters gene in ryegrass (Lolium perenne L.) plants. Plant Physiol Biochem 2018, 130, pp. 445-454.

Publisher's Note: MDPI stays neutral with regard to jurisdictional claims in published maps and institutional affiliations.

(C) 2020 by the authors. Submitted for possible open access publication under the terms and conditions of the Creative Commons Attribution (CC BY) license (http://creativecommons.org/licenses/by/4.0/). 